\title{
Pop-Existentialism in New Zealand
}

\author{
Dale Benson
}

Just after World War Two, when French existentialism was all the rage in Europe and North America, New Zealanders in New Zealand had relatively little opportunity to learn about existentialism or to read contemporary existentialist literature. While the following is by no means an exhaustive account of the books and magazine articles concerning existentialist ideas available in New Zealand during and after World War Two, it will nonetheless suggest that existentialist ideas evoked considerable popular interest in this country - particularly among the younger generation.

In 1941 an article from London entitled "The Book Trade" in Dunedin's Otago Daily Times confirms a shortage of books in wartime Britain when it relates, "thirty-seven thousand catalogued books available for purchase two years ago are now unobtainable owing to production difficulties." In 1943 another article in the Otago Daily Times expresses the shrinking volume of books in local terms: "In Dunedin an increasing demand has been brought about for second-hand books. War conditions have accentuated this.... The scarcity of good new literature has been very noticeable locally."1

The New Zealand government's stringent censorship of any literature that it felt might be injurious to the war effort also contributed to the shortage of imported books. According to Nancy M. Taylor in The New Zealand People at War: The Home Front, booksellers were frustrated and their businesses suffered because they could not be sure why their ordered books did not arrive. Was it administrative error, shipping delays, loss at sea or because they were being held by the censor's office? (2: 997) Taylor adds that because the Progressive bookshops in Auckland and Christchurch and Modern Books in Wellington "represented book demands which were in varying degrees leftist or intellectual" (that is, because their orders often included books the government deemed dangerous), they were hard hit by import restrictions (2: 1001). Taylor further reports how a customs warning against the importation of subversive literature caused The Official Bulletin of the New Zealand Library Association to recommend that the nation's libraries practise self-censorship. As a result, booksellers and librarians tended to order only "safe" books rather than risk money or their import licences on shipments that might be withheld (2: 1013).

\footnotetext{
${ }^{1}$ From a clipping file held in the McNab Collection at the Dunedin Town Library, Dunedin, Otago Daily Times, 6 Dec. 1941; 14 Apr. 1943.
} 
It is not surprising, therefore, that in The Official Bulletin of the New Zealand Library Association the lists of new acquisitions for New Zealand libraries are very short or non-existent during most of the 1940s. A survey of the Bulletin between 1939 and 1955 reveals that even a decade after the war, libraries acquired few works by acknowledged existentialist writers or about the existentialist philosophy. It is not until March of 1950 that the Bulletin records the acquisition of a translation of Jean-Paul Sartre's Intimacy and Other Stories for free issue. A translation of Sartre's Iron in the Soul is listed in the November Bulletin, with The Chips are Down listed the following November. Of the American existentialist writers, Richard Wright's The Outsider is listed in the fiction list for June of $1954 .^{2}$

According to Max Charlesworth in The Existentialists and Jean-Paul Sartre, the British philosophical community regarded continental existentialism poorly, even at the height of its popularity in the 1940s and 50s (28). A survey of New Zealand university calendars between 1935 and 1965 indicates that although all of the constituent colleges (later to become universities in their own right) have offered courses in Western Philosophy, existentialism was not studied as a formal philosophy. ${ }^{3}$ Even now it is not often studied in Philosophy departments, an indication perhaps that existentialism has had as little credit among professional philosophers in New Zealand as it has in England.

In fact, more New Zealanders have been exposed to existentialism as literature than as a formal philosophy. In Black Beech and Honeydew: An Autobiography, Ngaio Marsh recalls that in the early 1940s the Drama Society at Canterbury College of New Zealand staged Sartre's The Flies (264). Significantly, the production was in English, which would have made it accessible to a wider audience. Judging by a passage in Maurice Gee's Sole Survivor Albert Camus' The Myth of Sisyphus was well known, at least among university students and young professionals during the early 1950s. As Ray Sole says over coffee:

"You see, ... the way I look at it is that we've got a longing in us for happiness but the world is silent, or else it gives us back this idiot chatter. We've got a deep desire, a deep nostalgia really, for unity and the world disappoints us. Now in the face of all this, all we can do is struggle. The only weapons we have are strength and pride. The only truth we have is in defiance. Meaning is defiance. If there's any meaning. Ha! Another cup of coffee? Well anyway, that's how I see it."

\footnotetext{
${ }^{2}$ Held at the Alexander Turnbull Library, Wellington.

${ }^{3}$ Held at the Central and Hocken libraries at the University of Otago, Dunedin.
} 
Glenda Goodlad, one of Sole's audience, does not hesitate to identify the source of his ideas: "That's how Albert Camus sees it too.... Everyone I know is reading The Myth of Sisyphus. I wish they'd find another book" (92). Although in The Hangover Frank Sargeson does not explicitly identify any existentialist texts, he does examine New Zealand's provincial Puritanism against a background of existentialist ideas. Throughout the novella, Sargeson contrasts the puritanical values of his protagonist, Alan, with the vaguely held notions of a group of young beatniks and the rather more cynical world-view professed by Lennie Dick. Against Alan's naive "of course", "He would be an engineer - like his father" (Two Short Novels 9), Sargeson's narrative suggests that the future is not as predictable as Alan believes. After the unencumbered lifestyle of the beatniks disturbs the established verities of Alan's engineering studies, Lennie Dick's blandishments bring the protagonist's existential uncertainties to a crisis: "as though all he had taken for granted in his life was dislocated" (131). The older man's description in his journal of the cause and effect of this dislocation clearly reveals Sargeson's knowledge of popular existentialist ideas. In the passage below, for example, Dick's comparison of individuals to multi-layered onions recalls Sartre's warnings about living in mauvais foi or bad faith, when one does not remain true to one's convictions:

When the ego is so protectively wrapped up that it self-defeats all its endeavours to establish human relations, then it will try to find its own compensation by diffusing itself through the wrappings. But a stiff price will have to be paid - in the thinning out of the egoistic core. Immediate aims may be achieved in the sense that nerve endings succeed in reaching to the surface, thus appearing to establish some kind of contact with the outside world. But this will be largely a delusion. The contact will be strictly nervous, hence consistently very painful. Urgent need for another protective layer will soon become manifest (147-48).

According to Dick, the onion "is a series of wrappings wrapping nothing." His description of this central void foreshadows Alan's behaviour as he peels off three of the four plastic raincoats he had donned to murder those whose empty beliefs and actions had drained his own sense of validity.

Although there were no courses offered in Existentialism in Philosophy departments, Canterbury University College did offer in 1951 and 1952 French 237 for Masters and Honours-level study of an approved subject from twentiethcentury French literature or of an approved twentieth-century French author. It was not until the late 1950 s and early 60 s, however, that works by Camus and Sartre became required reading. 
When Lauris Edmond began extramural study through the Massey University College of Manawatu in 1963 she recalls in the second volume of her autobiography, Bonfires in the Rain, "French had changed," adding that

You had to speak the wretched language, not just recite verbs.... Plays were performed ... like Sartre's 'Huis Clos'. I was fascinated and appalled at the idea of hell being a cycle of constant small cruelties inflicted by one person on another and repeated through all eternity. This was part of another revolution in my mind and outlook, prompted ... by my first encounter with one of the great intellectual and philosophical movements of the century - existentialism (182).

Edmond's reading of Sartre and Camus fed her incipient feminism and confirmed that she had given up for good "supposing that God (whatever I meant by that) awaited me in the Anglican service." (185) She absorbed

a great deal about how [Sartre and Camus] arrived at their by then famous idea. 'L'absurde', I discovered, was a name for the anguish of modern man who wants to live forever but can no longer believe he will go to heaven when he dies. From there I followed them to 'moi, c'est mon projet': my life is my own, it is all I have; mine - since God will no longer take it for me - is the responsibility to find its meaning, to become (as they put it) 'authentic' (182-83).

Later Edmond would join women's groups: "I gave talks about selfdetermination, harnessed my knowledge of existentialism, the philosophy of personal responsibility, I held forth." (206). In 1968 she went to Wellington to attend the "Peace Power and Politics Conference," wanting especially to see Sartre (who did not manage to attend). Later she would read "On Genocide," the paper Sartre was to have given (208).

Some readers came across literary existentialism less formally, outside the university. Rhondda Bosworth, in her contribution to the Quote, Unquote article "Remembering Frank Sargeson," confirms Sargeson's interest in existentialist literature. "With Frank's encouragement," she recalls, "I read Camus, Sartre" and found that "existentialism was intoxicating" (14).

Despite the wartime dearth of imported books, numerous reviews of New Zealand fiction suggest an awareness of existentialist ideas since well before the early 60s. In a 1949 Listener piece on Erik de Mauny's The Huntsman in His Career, for example, Sargeson compares that novel to Cliffs of Fall by Dan Davin and notes that both authors unsuccessfully explore modern feelings of guilt and anxiety. Although Sargeson does not specifically use the word "existentialism" in his review, when he criticizes de Mauny for not sufficiently 
digesting a number of borrowed ideas he is probably referring to ideas borrowed from Sartre. (In 1948 de Mauny had published his translation of Sartre's Portrait of the Anti-Semite.) Sargeson's description of the hunting of Milsom also suggests an idea borrowed from Sartre, from Les Mains Sales (Bancroft 22), "that in politics it is necessary to get one's hands dirty":

In the human world which [Villiers] belongs to, such things happen, he cannot escape from participating in them. But since he chooses not to consent, he is a man tormented by feelings of responsibility and guilt, anxiety and doubt (12-13).

In his 1950 Landfall review of The Huntsman in His Career, D. H. Munro does not use the word "existentialism" either. Yet when he summarizes the novel's main idea, "that, since we are caught up in the network, we cannot help suffering and making others suffer: the important thing is to maintain one's own integrity" (357) he, too, is probably referring to de Mauny's Sartrean view of the human predicament.

As well as reviews, several magazines available in New Zealand published pieces that treat the topic of existentialism either implicitly or explicitly, in articles or in fiction. In 1945 and $1946 \mathrm{H}$. A. Mason contributed two articles to Scrutiny magazine: the first, "Existentialism and Literature: A Letter from Switzerland" criticizes Sartre's La Nausée and Les Mouches; the second, "M. Camus and the Tragic Hero," criticizes both the original and the English translation of Camus' L'Etranger. In 1945 A. J. Ayer published two critical studies of JeanPaul Sartre's philosophy in a series of articles about novelist-philosophers in Horizon. In 1950 his "Jean-Paul Sartre's Doctrine of Commitment" appeared in the British Listener. In 1946 a writer for the New Zealand Listener questions, in "This Word 'Existentialism': New Attack on the Ivory Towers," how long the new "-ism" would last:

Existentialism ... involves the theory that man must create his own essence by throwing himself into world affairs, suffering and battling for what he believes.... Above all, it is the theory that one cannot stand apart from life, but one must consciously take sides. (Kay 9)

In 1946 a New Zealand Listener article reprinted from the New Yorker, "Two Frenchmen of the Moment: Jean-Paul Sartre; Jean Bruller" describes Sartre as "the prophet of a new philosophy known as Existentialism, which has already divided France into two camps and is also beginning to cause intellectuals in other countries to trip over the party lines" (23). In 1949 Landfall published "In Defence of the Individual," H. H. Rex's inaugural lecture delivered at the 
Theological Hall, Knox College, Dunedin. ${ }^{4}$ In his lecture Rex distinguishes between collectivism and individuality, Hegel and Kierkegaard, describing the latter as "an 'existential' thinker" (111-23). Also in 1949 Hilltop, a literary journal produced by the Victoria University College Literary Society, published "The Fall" by Lorna Clendon. "The Fall" depicts a girl's fear that she is dying and ends with an existential question: "Now that she was living what would she do?" (4-5) Hilltop's successor, Arachne, published Erik Schwimmer's translation of "The Actor" from The Myth of Sisyphus in 1950. (10-13) The same issue of Arachne includes another Rex article, "Concerning Sartre":

The other day a young New Zealander touring at present the Continent, wrote to me, 'For good or for ill the existentialist approach seems to have made its way into almost every branch of life and thought on the Continent. Such a philosophy of despair, crystallizing as it does, thoughts of futility which must be in the minds of many people in our age, seems to me an extremely negative and dangerous contribution!' He was thinking of Sartre in particular. This is important to note, for existentialism covers a wide range of frequently contradictory views, ranging from militant atheism to orthodox Christianity and varying from an emphatic denial of the possibility of personal communion to an equally emphatic assertion of the reality of the 'we' (18).

In 1951 Landfall published Rex's “Existentialist Freedom”, which deals with Sartre's "uncompromising assertion that man is free" (209).

Parsons Packet, posted from Wellington by Roy Parsons between 1947 and 1955, confirms the relative scarcity of existentialist books in New Zealand during the 1940s and 50s. Notes on the inside of the front cover of the 1984 commemorative selection of pieces from Parsons Packet explain that Parsons' small periodical "was a means of bringing attention to books, bookish issues, and of course to the bookshop. There was, in New Zealand at that time, little other publishing of this kind." A number of the selected articles specifically refer to existentialist publications. In his February 1948 review of Louis Ferdinand Céline's Journey to the End of Night John Reece Cole comments that "something about recent reading, the Existentialist hysteria and gloom, the disconsolate subjectivism of Davin's recent war book [For the Rest of Our Lives] prompted me to turn back to Céline, surely one of the most sardonic and enigmatic figures who interpreted World War I and the aftermath" (Cole 6). The "Books to Come" section of the October/November issue of 1948 foreshadows the publication by Hamish Hamilton of Stuart Gilbert's translation of The Plague

\footnotetext{
${ }^{4}$ A detailed list of Rex's existentialist reading and lectures on Sartre and Dostoyevsky is provided by Albert C. Moore and Maurice E. Andrew in A Book of Helmut Rex: A Selection of His Writings with Memoirs of His Life and Work (Dunedin: University of Otago, 1980), 77n.
} 
by Albert Camus and provides a short review of The Victim by Saul Bellow. In the February/March issue of 1949 there is a brief description of Camus in the "People" section and an unfavourable review by David Hall of The Plague. In the June/July issue of 1949 there is a reprint of a satirical article by Delamore Schwartz from the Partisan Review entitled "Does Existentialism Exist?" In the same issue there is a brief description of Gabriel Marcel's The Philosophy of Existence. The March/April issue of 1950 describes Marcel's Research into the Essence of Spiritual Reality in "Books to Come," characterizing the author as the leader of the French school of Christian Existentialism. Also briefly described under "Books to Come" is Gerard Hopkins' translation of Iron in the Soul, the third instalment of Sartre's Road to Liberty. In the July/August issue of 1950 Parsons praises in "My Own Trumpet" an excellent Wellington production of Sartre's Crime Passionnel, even as he scorns newspaper reviews of the play. The May issue of 1953 describes Camus's The Rebel in the "Books to Come" section, which book is reviewed in the January/February issue of 1954. In the July/September issue of 1955 David Hall reviews the French edition of Les Mandarins by Simone de Beauvoir. In the last issue of Parsons Packet, October/December 1955, a brief description of Camus' Myth of Sisyphus is listed under "New and Forthcoming Books."

John Lehmann's Penguin New Writing was also available to New Zealand readers, ${ }^{5}$ but its circulation was international. In an essay in The Oxford History of New Zealand Literature charting the history of publishing, patronage and literary magazines in New Zealand, Dennis McEldowney attests to the success of the journal when he explains that "wartime emotion in Britain, both patriotic and vaguely socialist, turned it for a time into a best seller." Printed on "flimsy grey paper" it published the work of a handful of New Zealand writers who "achieved a very large audience indeed" (Sturm 573).

In 1954 James K. Baxter links one of Sargeson's Penguin New Writing stories with France's literary existentialism:

In That Summer the myth of the lost man who has no place in society and scarcely desires it is fully developed. One is struck immediately by the similarity of the world-view implied in this story and that which French existentialists have given a philosophical context and some French novelists a voice. (It is surely no accident that Sargeson's book was lately translated into French) (172).

\footnotetext{
${ }^{5}$ For the most recent edition of the stories, see Anthony Stones Celebration: An Anthology of New Zealand Writing from the Penguin New Writing Series.
} 
Baxter's reference is to Cet été-là, a translation of That Summer by Jeanne Fournier-Pargoire, published in Paris by Editions du Bateau-Ivre in 1946 (King 432).

Several Penguin New Writing stories from New Zealand have an existentialist flavour. Also by Sargeson: "A Great Day", when the scenery looks on indifferently as Fred abandons Ken to drown on a submerged reef; "An Affair of the Heart", a love story that makes no assumptions about the nature of love; "The Making of a New Zealander", which suggests that the situation of the protagonist, Nick the Dalmatian, can never be fixed; and When the Wind Blows, in which Henry realizes that his life is as random as the wind and he does not know anything. Three war stories, Dan Davin's "Under the Bridge" and Erik de Mauny's "In Transit" and "A Night in the Country," concern characters who realize not only that they do not know anything, but also that they cannot know anything. Because they experience events in front of an indifferent natural backdrop, their problems and successes alike are without meaning. Greville Texidor contributed two short stories she had written in New Zealand: "Epilogue" suggests that values are meaningless because war kills both pacifists and combatants, and "Santa Cristina" shows that everything is subject to entropy.

Finally, Anna Kavan's “The Red Dogs” portrays through Lehmann's journal one of the most compelling visions of twentieth-century anxiety to come out of New Zealand. The dogs are alien carnivores that conquer an unidentified country and devour its inhabitants. Although death is still inevitable, nothing else in the story behaves according to familiar rules. Compared to Ray Sole at the coffee house, Kavan's monsters evoke horribly accelerated images of the shedding of significance. Yet both stories suggest that when French Existentialism was popular in Europe and North America it was also evident in New Zealand literature, reflecting the loss of God, the failure of science to ameliorate the human condition and the exhaustion caused by global warfare, when existentialism was "in the air."

\section{Works Cited}

Ayer, A. J. "Novelists-Philosophers V - Jean-Paul Sartre." Horizon 12 (July 1945): 12-26; (Aug. 1945): 101-110.

Bancroft, L. D. Sartre's “Les Mains Sales": Some Talking Points Canterbury Monographs for Teachers of French, no. 4. Christchurch: University of Canterbury Department of French, 1975.

Baxter, James K. "Back to the Desert," in James K. Baxter as Critic. Ed. Frank McKay. London: Heinemann Educational Books, 1978. 
Bosworth, Rhondda. "Sargeson and Women" in "Remembering Frank Sargeson," Quote, Unquote Nov. 1995: 14.

Charlesworth, Max. The Existentialists and Jean-Paul Sartre. London: Prior, 1976.

Clendon, Lorna. "The Fall." Hilltop 3, no. 3 (Sept. 1949): 4-5.

Cole, John Reece. "Céline and the War Novelists." Rev. of Journey to the End of Night, Louis Ferdinand Céline. Parsons Packet (Feb. 1948): 6.

Edmond, Lauris. Bonfires in the Rain. Wellington: Bridget Williams, 1991.

Gee, Maurice. The Plumb Trilogy. Auckland: Penguin, 1995.

Kay, pseud. "This Word Existentialism: New Attack on the Ivory Towers." Listener 14, no. 354 (5 Apr. 1946): 9.

King, Michael. Frank Sargeson: A Life. Auckland: Viking, 1995.

Marsh, Ngaio. Black Beech and Honeydew: An Autobiography. Auckland: Collins, 1966.

Mason, H. A. "Existentialism and Literature: A Letter from Switzerland." Scrutiny 13 (Sept. 1945): 82-98; "M. Camus and the Tragic Hero." Scrutiny 14 (Dec. 1946): 82-89.

McEldowney, Dennis. "Publishing, Patronage, Literary Magazines," in The Oxford History of New Zealand Literature in English. Ed. Terry Sturm. Auckland: Oxford University Press, 1991.

Moore, Albert C. and Maurice E. Andrew, eds. A Book of Helmut Rex: A Selection of His Writings with Memoirs of His Live and Work. Dunedin: University of Otago, 1980.

Munro, D. H. Rev. of The Huntsman in His Career, by Erik de Mauny. Landfall 4 (Dec. 1950): 356-7.

Official Bulletin of the New Zealand Library Association. Held at the Alexander Turnbull Library, Wellington.

Otago Daily Times [Dunedin]. Clipping file. McNab Collection, Dunedin Town Library, Dunedin.

Parsons Packet April 1947-October/December 1955: A Selection Compiled for Roy Parson on the Occasion of His Seventy-fifth Birthday 1984 by the Parson Family and Bridget Williams. Wellington: Parsons Bookshop, 1984.

Rex, H. H. "Concerning Sartre." Arachne 1, no. 1 (Jan. 1950): 18-21.

—. "Existentialist Freedom." Landfall 5 (Sept. 1951): 209-16.

_. "In Defence of the Individual." Landfall 3 (June 1949): 111-23.

Sargeson, Frank. Rev. of The Huntsman in His Career, by Erik de Mauny. Listener 21, no. 543 (16 Sept. 1949): 12-13.

_. Two Short Novels: The Hangover and Joy of the Worm. 1967, 1969; rpt. Auckland: Penguin, 1984.

Sartre, Jean-Paul. Portrait of the Anti-Semite. Trans. Erik de Mauny. London: Secker and Warburg, Lindsay Drummond, 1948.

Schwimmer, Erik, trans. "The Actor," by Albert Camus. Arachne 1, no. 1 (Jan. 1950): 10-13.

Stones, Anthony, ed. Intro. John Lehmann. Celebration: An Anthology of New Zealand Writing from the Penguin New Writing Series. Auckand: Penguin, 1984.

Taylor, Nancy M. The New Zealand People at War: The Home Front, Official History of New Zealand in the Second World War 1939-1945. 2 vols. Wellington: Historical Publications Branch Dept. of Internal Affairs, Government Printer, 1986. 
"Two Frenchmen of the Moment." Listener 14, no. 362 (31 May 1946): 23.

Kōtare 5, no. 1 (2004), pp. 18-27. 